\title{
A corrected lectotypification of Artemisia umbrosa $(=A$. vulgaris var. umbrosa, Asteraceae)
}

\author{
Sergei L. MOSYAKIN ${ }^{1}$, Ganna V. BOIKO ${ }^{1}$, Filip VERLOOVE² \\ ${ }^{1}$ M.G. Kholodny Institute of Botany, National Academy of Sciences of Ukraine \\ 2 Tereschenkivska Str., Kyiv 01004, Ukraine \\ s_mosyakin@hotmail.com \\ bav22@ukr.net \\ ${ }^{2}$ Botanic Garden of Meise \\ Nieuwelaan 38, B-1860 Meise, Belgium \\ filip.verloove@plantentuinmeise.be
}

Mosyakin S.L., Boiko G.V., Verloove F. A corrected lectotypification of Artemisia umbrosa (= A. vulgaris var. umbrosa, Asteraceae). Ukr. Bot. J., 2018, 75(4): 335-337.

Abstract. A corrected lectotypification of the name Artemisia umbrosa (= A. vulgaris var. umbrosa, Asteraceae) is discussed. It is demonstrated that Besser (1832) in fact cited in the protologue four concrete specimens that should be thus treated as syntypes. Following Art. 9.3 and 9.12 of the International Code of Nomenclature for algae, fungi, and plants (Shenzhen Code, Turland et al., 2018), the earlier lectotype designation by Korobkov (2014) is superseded, and one of the syntypes is designated here as the lectotype, the specimen KW001000452 from the Besser historical herbarium at the National Herbarium of Ukraine (KW).

Keywords: Artemisia, Asteraceae, alien species, nomenclature, typification, lectotype

In our recent article (Mosyakin et al., 2018) we discussed the correct authorship and nomenclature of the name Artemisia umbrosa (Turcz. ex Besser) Turcz. ex Verlot (1875: 12, non vidi; Verlot 1876: 73) (A. vulgaris var. umbrosa Turcz. ex Besser; see Besser, 1832: 52; 1834: 52) applicable to the rather widespread East Asian species currently known as introduced and locally naturalized in several European countries, especially in Eastern Europe (Ukraine, Russia, Belarus, Lithuania, Latvia, etc.) (see an overview and references in Mosyakin et al. 2018; an article on new records from some additional European countries is in preparation by Verloove et al.). The available original specimens (mainly those from $\mathrm{KW}, \mathrm{G}, \mathrm{H}$, and LE; herbarium acronyms following Thiers, 2018-onward) and the lectotypification of the name proposed by Korobkov (2014: 15) were also briefly discussed. We concluded that "the lectotype designation by Korobkov (2014) was not the best available choice (see comments and the list of other original specimens below). However, the current wording of Art. 9.19 of the ICN (McNeill et al., 2012) gives no solid reason for rejection of his lectotypification because the lectotype specimen belongs to original material in the extended sense of Art. 9.3 of the ICN (McNeill et al., 2012)". However, this conclusion has to be corrected (C) S.L. MOSYAKIN, G.V. BOIKO, F. VERLOOVE, 2018 and updated in view of Art. 9.3 and 9.12 of the newly released Shenzhen Code (Turland et al., 2018). The same provisions were included in Art. 9.2 and 9.12 of the Melbourne Code (McNeill et al., 2012).

In our article (Mosyakin et al., 2018: 217) we already noted that, when describing his $A$. vulgaris var. umbrosa, Besser (1832: 52; 1834: 52) cited at least four concrete specimens: "a) Talis ad Selengam in umbrosis Turtschan. b) Eadem paniculæ ramis inferioribus longioribus, sine loco indicato Adams (herb. Acad. Imp. Sc.). c) Eadem caule paniculato foliis summis brevioribus, sine patria indicata Gmel. jun. (in eodem herbario). d) Foliorum trifidorum lacinia media vix reliquis longiore, panicula majore, spicis inferioribus magis elongatis, suberectis. Ad eandem Selengam legit Adams (idem herb.)". These specimens should be considered syntypes and their duplicates are thus isosyntypes.

In contrast, Korobkov (2014: 15) designated the following specimen from LE as the lectotype: "Lectotypus (Korobkov, hic designatus) et isolectotypi (3): Восточная Сибирь, Бурятия, "In umbrosis Charatzai, in insulis Selenga, 1829 [fl.], Turczaninov (Herb. Ledebour)" (LE)". He also cited as "syntypes" three specimens with the labels "In humidis Dahuria Nerrcziensis [sic! - S.M., G.B., \& F.V.], 1831, Turczaninov". However, the localities "Charatzai" 
[corresponding to Kharatsay (Харацай in Russian, Xapacaa in Buryat) in Zakamensky District (Закаменский район in Russian; Захааминай аймаг in Buryat) in the Republic of Buryatia, Russia] and "Dahuria Nercziensis" (Nerchinsk) were not reported by Besser (1832) in the protologue. The locality "Charatzai" was mentioned by Ledebour under A. selengensis var. umbrosa (Turcz. ex Besser) Ledebour (1845: 585): "Hab. in Sibiria transbaikalensis in insulis fl. Selenga! et alibi inque Davuria ad Charatzai! (Turcz.)". That publication, however, is not the protologue of $A$. vulgaris var. umbrosa. The mention of "Charatzai" evidently refers to one of the specimens provided by Turczaninow directly to Ledebour or to the St. Petersburg herbarium (now LE). It should be also noted that $A$. selengensis Turcz. ex Besser (1832: 50; 1834: 50) is now accepted as a species distinct from A. umbrosa.

Thus, the lectotype designation by Korobkov (2014) is not in conformity with Art. 9.12 of the ICN (Turland et al., 2018), which, in particular, states that "in lectotype designation, an isotype must be chosen if such exists, or otherwise a syntype or isosyntype if such exists". According to Art. 9.3 of the ICN (Turland et al., 2018), "A lectotype is one specimen or illustration designated from the original material (Art. 9.4) as the nomenclatural type, in conformity with Art. 9.11 and 9.12 , if the name was published without a holotype $<\ldots>$...

Consequently, the lectotype designation by Korobkov (2014) was made contrary to Art. 9.3 and 9.12. The lectotype of the name $A$. vulgaris var. umbrosa (the basionym of $A$. umbrosa) is designated below. It is one of the syntypes cited by Besser (1832: 52; 1834: 52), the one indexed by him with the letter "d)".

Artemisia umbrosa (Turcz. ex Besser) Turcz. ex Verlot, Catalogue des graines du Jardin botanique de Grenoble, 1875: 12. 1875 (Verlot, 1875: 12, non vidi); Verlot in Bull. Soc. Dauphin. Échange Pl. [Première série] 3: 73. 1876 (Verlot, 1876: 73, reprinted text from Verlot, $1875) . \equiv$ A. vulgaris L. var. $[\alpha]$ umbrosa Turcz. ex Besser, Tentamen de Abrotanis seu de sectione II ${ }^{\text {da }}$ Artemisiarum Linnoei [Moscow]: 52.1832 (Besser, 1832: 52, preprint); Besser, Nouv. Mém. Soc. Imp. Naturalistes Moscou 3: 53. 1834 (Besser, 1834: 52, bound volume). $\equiv$ A. selengensis Turcz. ex Besser var. [ $\beta$ ] umbrosa (Turcz. ex Besser) Ledebour, Fl. Ross. 2(2), part 6: 584. 1845 (Ledebour, 1845: 584).
Type (lectotype, here designated):-RUSSIA: Zabaykalskiy Kray (Trans-Baikal Province) or the Republic of Buryatia: "Artemisia (Abrotanon) vulgaris $\alpha$ A. umbrosa Turc. d) Ad Selengam Adams (Hbr. Ac. I. Sc.) [from the herbarium of the Imperial Academy of Sciences, St. Petersburg - S.M., G.B. \& F.V.]. Herb. W. Besser", KW001000452 (Besser's label, blue paper identical to paper used for publication of the Catalogue... by Besser, 1810; on the same sheet with KW001000453; image available from: https:// plants.jstor.org/stable/10.5555/al.ap.specimen. kw001000452, and reproduced in Mosyakin et al., 2018: 220, fig. 3, two right-hand plant fragments).

\section{Acknowledgments}

We are grateful to the reviewers for their useful comments.

\section{REFERENCES}

Besser W. [W.S.J.G.]. Catalogue des Plantes du Jardin Botanique de Krzemieniec en Volhynie. [Kremenets], 1810, $88 \mathrm{pp}$.

Besser W.S. [W.S.J.G.]. Tentamen de Abrotanis [typo: "Abotanis"] seu de sectione II da Artemisiarum Linnoei (Extrait des Nouveaux Mémoires de la Société Impériale des Naturalistes de Moscou, Tome III). [Preprint, Moscow], 1832, 92 pp. +5 tab. Available from: https://catalog.hathitrust. org/Record/011553698

Besser W.G. [W.S.J.G.]. Tentamen de Abrotanis seu de sectione II-da Artemisiarum Linnæi. Nouveaux Mémoires de la Société Impériale des Naturalistes de Moscou, 1834, 3: 3-89.

Korobkov A.A. Type specimens of taxa of Artemisia L. (Asteraceae) from Siberia and the Far East kept in the Herbarium of V.L. Komarov Botanical Institute. Turczaninowia, 2014, 17(2): 5-6. [Коробков А.А. Типовые образцы таксонов рода Artemisia L. (Asteraceae), описанных из Сибири и Дальнего Востока, хранящихся в Гербарии Ботанического института им. В.Л. Комарова. Turczaninowia, 2014, 17(2): 5-6]. http://old.ssbg.asu.ru/turcz/turcz_17_2_05_16.pdf

Ledebour C.F. Flora Rossica; sive, Enumeratio plantarum in totius Imperii Rossici provinciis Europaeis, Asiaticis et Americanis hucusque observatarum. Stuttgartiae [Stuttgart]: Sumtibus Librariae E. Schweizerbart, 1845, vol. 2(2), part 6, pp. 463-718. [Vol. 2 published in parts during 1843-1846; vi + 937 pp.]. https://doi. org/10.5962/bhl.title.6606

Mosyakin S.L., Verloove F., Boiko G.V. The correct authorship and nomenclature of Artemisia umbrosa (Asteraceae), with comments on some misapplied names and distribution of the species in Eastern Europe. Ukrainian Botanical Journal [Український ботанічний журнал], 2018, 75(3): 213-229. https://doi.org/10.15407/ ukrbotj75.03.213 
McNeill J., Barrie F.R., Buck W.R., Demoulin V., Greuter W., Hawksworth D.L., Herendeen P.S., Knapp S., Marhold K., Prado J., Prud'homme van Reine W.F., Smith G.F., Wiersema J.H., Turland N.J. International Code of Nomenclature for algae, fungi, and plants (Melbourne Code): Adopted by the Eighteenth International Botanical Congress, Melbourne, Australia, July 2011. Regnum Vegetabile, 2012, 154: 1-274.

Thiers B. (2018-onward) Index Herbariorum. A global directory of public herbaria and associated staff. New York Botanical Garden's Virtual Herbarium. Available at: http:// sweetgum.nybg.org/science/ih (accessed: 2 July 2018)

Turland N.J., Wiersema J.H., Barrie F.R., Greuter W., Hawksworth D.L., Herendeen P.S., Knapp S., KusberW.-H., Li D.-Z., Marhold K., May T.W., McNeill J., Monro A.M., Prado J., Price M.J., Smith G.F. International Code of Nomenclature for algae, fungi, and plants (Shenzhen Code) adopted by the Nineteenth International Botanical Congress Shenzhen, China, July 2017. Regnum Vegetabile, 2018, 159: i-xxxviii + 1-254. https://doi.org/10.12705/Code.2018

Verlot J.-B. Catalogue des graines du Jardin botanique de Grenoble, 1875. Grenoble, 1875 [non vidi].

Verlot J.-B. Artemisia umbrosa Turcz. [Note extraite du Catalogue des graines du Jardin botanique de Grenoble, 1875, par M. J.-B. Verlot]. P. 73 in: [Anonymous]. Notes sur quelques espèces distribuées cette année [1876]. Bulletin de la Société Dauphinoise pour l'Échange des Plantes [Première série], 1876, 3: 69-84.

Recommended for publication by

Submitted 20.07.2018
Мосякін С.Л. ${ }^{1}$, Бойко Г.В. ${ }^{1}$, Верлоов Ф. ${ }^{2}$ Уточнена лектотипіфікація Artemisia umbrosa (= A. vulgaris var. umbrosa, Asteraceae). Укр. бот. журн., 2018, 75(4): 335-337.

${ }^{1}$ Інститут ботаніки ім. М.Г. Холодного НАН України вул. Терещенківська 2, Київ 01004, Україна

${ }^{2}$ Ботанічний сад Мейсе,

Нівелаан 38, В-1860 Мейсе, Бельгія

Обговорено та уточнено лектотипіфікацію назви Artemisia umbrosa (= A. vulgaris var. umbrosa, Asteraceae). Показано, що Бессер (Besser, 1832) насправді процитував у протолозі чотири конкретні зразки, які мають розглядатися як синтипи. Відповідно до статей 9.3 та 9.12 "Міжнародного кодексу номенклатури водоростей, грибів та рослин" ("Шеньчженський кодекс", 2018), попередню лектотипіфікацію (Коробков, 2014) відхилено, а один 3 синтипів - зразок KW001000452 з історичного гербарію Бессера у Національному гербарії України (KW) обраний тут як лектотип.

Ключові слова: Artemisia, Asteraceae, адвентивний вид, номенклатура, типіфікація, лектотип

Мосякин С.Л. ${ }^{1}$, Бойко А. В. ${ }^{1}$, Верлоов $Ф .{ }^{2}$ Уточненная лектотипификация Artemisia umbrosa (=A. vulgaris var. umbrosa, Asteraceae). Укр. бот. журн., 2018, 75(4): 335-337.

${ }^{1}$ Институт ботаники им. Н.Г. Холодного НАН Украины ул. Терещенковская 2, Киев 01004, Украина

${ }^{2}$ Ботанический сад Мейсе, Нивелаан 38, Мейсе В-1860, Бельгия

Обсуждена и уточнена лектотипификация названия Artemisia umbrosa (= A. vulgaris var. umbrosa, Asteraceae). Показано, что Бессер (Besser, 1832) в действительности процитировал в протологе четыре конкретных образца, которые должны рассматриваться как синтипы. Согласно статьям 9.3 и 9.12 "Международного кодекса номенклатуры водорослей, грибов и растений" ("Шеньчженский кодекс", 2018), предыдущая лектотипификация (Коробков, 2014) отклонена, а один из синтипов - образец KW001000452 из исторической коллекции Бессера в Национальном гербарии Украины $(\mathrm{KW})$ избран здесь в качестве лектотипа.

Ключевые слова: Artemisia, Asteraceae, адвентивный вид, номенклатура, типификация, лектотип 